\title{
Papers
}

\section{The UK high street: Current issues and their implications}

Received (in revised form): 14 October 2005

\section{Dominic Allport}

is an associate at Gerald Eve, an independent firm of chartered surveyors and property consultants. He is head of retail and leisure research, and has considerable experience in strategic research analysis and consultancy.

\begin{abstract}
This paper assesses how and to what extent ten key issues currently affecting the UK high street constitute a threat or risk to its ongoing viability as a trading location. The implications of these factors for retail businesses are also drawn out and discussed.
\end{abstract}

\section{Keywords:}

high street, town centres, key issues, key costs

\section{The continuing importance of the high street}

\section{THE CHANGING LANDSCAPE OF UK RETAILING}

The UK retail landscape has undergone fundamental change over the course of the last 30 years. Not only has there been a considerable shift in the balance of power between retailer and manufacturer, but, just as critically, a much more complex and increasingly polarised set of trading locations and formats have evolved. ${ }^{1}$ Both have been brought about by ongoing changes in consumer demand as well as retailers' continuing drive for improved economies of scale and scope, resulting in a strong degree of industry consolidation and a widening gap between the few retailers currently enjoying strong growth and the remainder. This divergence between the best and the rest is also seen in terms of retail locations, with successful retail centres pulling away from their weaker, more secondary rivals.

The proliferation of trading locations and formats has meant that the UK high street has seen some of its historic importance erode away, with other distribution channels gaining in significance, be they out-of-town retail space or virtual retail space (such as the internet). Nonetheless, suggestions that the high street is doomed, or has had its day, appear wide of the mark. The high street has been under threat since the $1970 \mathrm{~s}^{2}$ but still remains the principal channel of distribution, continuing to be fundamental to the retail offer in most markets, regardless of the increasing raft of issues and costs associated with it. 
Despite its decline, the high street, including in-town shopping centres, still accounts for around 50 per cent of all UK retail space and roughly 50 per cent of all retail sales. This amounts to over 300 million square feet of net selling space and more than $£ 120 \mathrm{bn}$ in sales. ${ }^{3}$ In many major retail markets, town-centre space continues to dominate the retail hierarchy. In addition, town centres, particularly those above a certain catchment size, remain the principal choice for comparison goods purchases.

\section{CURRENT ISSUES AFFECTING THE UK HIGH STREET}

Ten key drivers, each significant in its own right, are impacting on the UK high street. These factors are not exclusive to the high street, but together they are threatening not just its continued health but the ongoing health of many of the retailers located there:

- the economy

- the consumer

- the internet

- supermarkets

- deflation

- costs

- planning

- mezzanines

- development pipeline

- physical configuration of stores.

The impact on rental growth

\section{The slowing economy}

Gradual increases in interest rates over the past two years have successfully reduced house price inflation, mortgage equity withdrawals and consumer expenditure. Currently, debt and debtservicing levels remain high and consumer confidence fragile. Increases in National Insurance contributions, higher utility bills and above-inflation council tax rises have all culminated in making the consumer less willing to go shopping. The quarter of a percentage point decline in interest rates in August 2005 is unlikely to have made much difference, although it does appear to mark the end to the cycle of rising base rates.

So far, the consumer slowdown has been relatively restrained. Yet the reduction in retail sales growth is likely to have implications for retail rental growth going forward, despite some evidence of retail rents showing signs of resilience. ${ }^{4}$ The longer the decline in retail sales growth continues, the greater the chances of weaker retail rental growth. Since 2000, town-centre retail rental growth has failed to rise above its ten-year average growth figure, ${ }^{5}$ a period which coincided with strong retail sales. Looking forward five years, retail, be it in town or out of town, is likely to see weaker sales growth than has been the case over the past five years. As a consequence, all things being equal, the chances of weak rental growth increase, with secondary locations (both in town and out of 


\section{Flexibility is required by retailers}

\section{The consumer is evolving}

town) coming under potentially greater pressure than prime retail markets.

In the short term, the out-of-town retail sector will be among the hardest hit, with several other retailers likely to suffer the same fate as Furnitureland, Kausser and Courts. The slowdown in the housing market has led to a reduction in related purchases, principally in the DIY and furniture sectors, but, thus far, this has not yet fed through to a significant reduction in rental increases, as demand for out-of-town retail property continues to outstrip supply. Rental increases could yet slow, however, as there is often a time lag between a downturn in consumer spending and a retailer's rent review. Beyond the next year or so, the supply of out-of-town space should increase, coinciding with a likely improvement in consumer spending. Out-of-town like-for-like sales growth is forecast to accelerate ahead of its in-town equivalent, ${ }^{6}$ bolstered by a possible recovery in the housing market. In the meantime, with many retailers' margins under continuing pressure from price deflation, as well as other macroeconomic issues such as higher oil prices and exchange rate issues, the choice of location and the amount of rent associated with a shop unit remain of paramount importance.

\section{Consumer trends}

Sales growth on the high street is not only influenced by the overriding economic situation but is also affected by changes in consumer lifestyles. These include an increase in car ownership, longer working hours, a greater number of women in the workforce, the rise of single households, the concept of the onestop shop, greater sensitivity to price and a rejuvenated interest in city living.

The need for greater flexibility from retailers, not only those located in town, is paramount in order to be able to respond best to these and other changes in society - some increasing demand for high-quality retail and leisure offerings in town, others clearly encouraging out-of-town development. In order to adapt, retailers need to be able to manifest flexibility in many ways; for example, by trading through a wide variety of store sizes and formats, by extending opening hours, by gaining in-depth knowledge about consumer behaviour and by being able to micro-manage stock levels and display according to location and time of day. None of these is a new concept, but their importance in terms of gaining competitive advantage has increased.

Shifts in the make-up of the population structure are also affecting the potential number of consumers for key product categories. Key changes, such as the slowing birth rate, the ageing of the baby-boomer generation and the male population growing faster than its female counterpart, will clearly have a number of implications for retailers. For many mid-market operators the key decision to be made will be whether to stay faithful to their core 


\section{The blending of retail and leisure}

\section{Designer wear versus valuewear}

\section{Downward pressure on prices}

\section{Retail theatre: A way of differing the offer}

shopper profile, which will probably age and have diminishing levels of disposable income, or alternatively adjust their offer to attract a new, younger, perhaps more affluent shopper.

Another trend that is reflecting changes in consumer lifestyles is the ongoing convergence between retail and leisure property. Many new shopping centres and high streets, particularly in areas of high income and high population density, are actively seeking to include a mix of leisure facilities such as restaurants, bars and cinemas alongside the traditional retail offer. In this way, consumer destinations, be they shopping-led, leisure-led or a combination of both, are created.

Since the late 1970s spending on leisure services has not only doubled its share of total household expenditure but has become less volatile, which would imply that it is now not considered as discretionary spending. The end result of having a good mix of branded retail and leisure provision is that it not only maintains the vitality of the town centre but also encourages consumers to travel from further to visit, to increase dwell time and ultimately to spend more money.

\section{The consumer and high-street polarisation}

Consumers' increased price sensitivity is both a cause and an effect of the polarisation that has occurred among retail operators, particularly in the clothing and footwear sector.

At one end of the scale are the aspirational brands and retailers, many of which have successfully expanded their consumer appeal without alienating their core customer base. At the other end of the scale are the value retailers, including Primark, Matalan, TK Maxx, as well as Tesco and (George at) Asda. The latter two are wellknown supermarkets that have been expanding rapidly into nonfood sectors such as clothing and footwear. In all, since 2000 value retailers have seen clothing and footwear sales grow four times faster than overall sales of clothing and footwear. ${ }^{7}$

As a result of the expansion of the value sector, coupled with an increased 'promiscuity' on the part of the consumer, mid-market operators such as Marks \& Spencer have seen customers choose to shop elsewhere. These companies have ultimately had to bow to an almost constant downward pressure on price and readjust their pricing policies to reflect this changed retailing environment, meaning that efficiency gains are needed to avoid keener prices resulting in deteriorating margins.

Another, less significant yet highly visual, way in which retailer polarisation is occurring is through retail theatre. Although difficult to qualify, the consumer is said to be more demanding than ever, typically expecting a shopping experience rather than just another shopping trip. Recent debate has centred on the purported 'sameness' of many retail locations, with suggestions that a select band of multiple retailers and brands are ever-present on many high streets, leading to a loss of individual character. ${ }^{8}$ Coupled with 


\section{The rise and rise of internet shopping}

this is the fact that consumers have more choice than ever as to what to do with their leisure time. As a result, in-town retail premises, particularly in competitive prime locations, have to put as much emphasis on selling themselves as on the products they offer inside.

Consumers' expectations have been raised by the appearance of eye-catching buildings such as the Selfridges store in Birmingham's Bullring. Now a tour around the local shops might be expected by many to come with some sort of entertainment value attached, something new in terms of store format rather than just everyday, utilitarian boxes. Hence the rise of retail theatre, the development of innovative and eye-catching retail interiors (and exteriors) that enhance the environment in which products are sold. This trend is most prominent among retailers that cater for the aspirational shopper, department stores and designer-wear outlets for example, but an increased reliance on imaginative store design to capture trade clearly has implications for store fit-out costs, which is a lessthan-ideal scenario during times of retailer margin pressure. Stores such as these carry with them a heightened degree of risk for retailers, because these stores often result in higher than average cost-to-turnover ratios.

\section{The consumer and technology}

Changes in consumer behaviour are often caused by a greater acceptance of certain technology. This has clearly been the case with rising levels of car ownership, with many households now having access to more than one car. The effects of this on the retail sector are clear to see, with the proportion of shopping trips made by car steadily on the increase. ${ }^{9}$ The arrival of the internet might one day have a similarly large impact.

As the internet's popularity has increased, to the point where it recorded sales of $£ 14.5 \mathrm{bn}$ in $2004,{ }^{10}$ it has heightened price deflation in key product categories and helped deflect sales away from the high street. Unsurprisingly, it is dominant retailers such as Tesco and Next that currently hold a key share of the online market, if one ignores pure-play retailers such as eBay and Amazon. Already the increased popularity of online retailing has led to increased retail consolidation, particularly among retail service providers such as travel agents, estate agents and insurance brokers. Booksellers and electrical retailers are other sectors to be affected. If a 15 per cent decline in footfall is sufficient to make certain retail outlets unprofitable, ${ }^{11}$ then branch rationalisation, as witnessed within the financial services sector, can be said to be another clear consequence.

In April 2005, sales through the internet represented about 7 per cent of all retail sales, and predictions by Interactive Media Retail Group are for online retailing to take a 20 per cent share of the retail market by $2010 .{ }^{12}$ Among clothing and footwear retailers, 


\section{The internet's impact on the high street}

\section{Why the likes of Tesco succeed}

mid-market operators such as Next have been some of the most enthusiastic adopters of online retailing. In some ways, then, the internet has aided retailers which have a strong presence on the high street, meaning that it can, to an extent, be viewed as a complementary selling channel.

At the same time, however, the high street, as a channel through which to do business, has been marginally undermined. Since 2001 the amount of retail trading space has expanded three times faster than the corresponding rise in sales per square foot. This relative decline in sales densities could easily be blamed on the increasing popularity of internet shopping, but the situation is complicated by other factors, including deflation and the ongoing expansion of outof-town retail space, where sales per square foot tend to be lower than they are in town. Nonetheless, there is no denying the fact that there is now nothing stopping consumers, having first visited a number of retail outlets to compare products, ultimately deciding to buy online on the basis of price and convenience.

Should shopping over the internet continue to expand as it has, a store-opening programme, one of the principal routes to expansion, might begin to make less business sense than it once did. In addition, such a trend could be reinforced by the ongoing concentration of retail locations. In terms of premises, the increasing use of the internet could eventually lead to a smaller amount of storage space being needed by many retailers, as a greater proportion of their product range, particularly bulkier items, is sold exclusively online.

\section{The supermarkets}

One of the main issues affecting the ongoing viability of the high street has been the expansion of the grocery sector out of town. The growth of the supermarkets continues apace, underpinned by consumer demand for extended trading hours and free parking. The move to a multi-format proposition is a key feature of successful retailing, and in the grocery sector Tesco has best exemplified this approach.

Tesco not only accounts for around 30 per cent of the UK grocery market (and 13 per cent of all retail sales), but also operates a thriving range of store formats ranging from units below 3,000 square feet to hypermarkets over 100,000 square feet. In addition, it has its successful online retailing presence. ${ }^{13}$ Such variety in trading formats shows the degree of flexibility Tesco has nurtured in its efforts to become more adaptable (and more profitable), learning to tailor both its store requirements and its product range to make the best of a location or catchment area. Most retailers tend to be less flexible in their approach and more reliant on a small number of trading formats.

In addition, the move into non-foods has been very successful for supermarkets, particularly in product areas such as clothing and footwear, homewares and books, music and DVDs. Such a move 


\section{A proliferation of stand-alone non-food stores to come}

\section{Why price deflation is happening}

\section{An increasingly price- sensitive customer}

has suited the supermarkets, as it has allowed them to achieve higher margins and better sales growth than would otherwise be available if they had concentrated solely on the selling of groceries. Tesco has been able to use the margin it has gained via its nonfood sales to support the lowering of grocery prices and thus reinforce its position as the leading supermarket operator.

To date, Asda has opened several stand-alone clothing stores, mainly in town, and is testing a homeware store format. Tesco is soon to follow suit with its own non-food stores (trials of which will be located out of town). Should both firms build sizeable chains of stand-alone, non-food stores and, due to national planning restrictions, a continued move towards ever more varied, multi-format trading remains probable, it could well have a significant impact on the high street, although one which is not necessarily detrimental. Such a move will pose a certain threat in terms of trade draw and pricing for particular sector specialists such as clothing retailers. But one benefit, if the supermarket operators choose to open many non-food stores in town, should be to encourage improved footfall, in terms of both quantity and quality, as well as enhance the potential of additional consumer expenditure for other retailers located there.

\section{Deflation}

Since 1996 the Consumer Price Index (CPI), the UK's main measure of inflation for macroeconomic purposes, has risen by 14 per cent. Yet the price of goods (which covers the majority of items sold in shops) has not kept pace with this increase. In fact, according to the CPI, the price of goods has declined by 2.6 per cent over the same period. To a large extent this is a reflection of the shift in power from manufacturer to retailer. As retailers have grown in size they have been able progressively to dominate supplychain relationships, resulting in a reduced cost base and, occasionally, even an improvement in profit margins.

With the abolition of quotas under the World Trade Organization's Agreement on Textiles and Clothing, from January 2005 prices are likely to drop further. The ability to source products directly from countries where the costs of production are lower has helped retailers enormously, in terms of both cost and control. A further factor has been the depreciation of the dollar. Within many global consumer goods markets, production capacity now outstrips consumer demand, resulting in a surplus of stock and an increased likelihood of product discounting.

Combined, these factors have made the UK consumer increasingly sensitive to price, a situation made easier by almost universal access to the internet where price comparison is simple. As a result, price competition among retailers has intensified as they have sought to maintain market share, yet research indicates that product quality has not been compromised. ${ }^{14}$ Many retailers (such as the value clothing sector) now base their entire business models 
The consequences of deflation

\section{The cost \\ disadvantages of the high street}

\section{Stamp duty land tax}

on offering permanently low prices. These retailers have not yet reached the levels of market share witnessed in either the USA or mainland Europe.

Advantages of scale mean that the larger, more dominant retailers are better equipped to survive in a climate of constant price cuts, especially those retailers that are not overly reliant on a single product category. Price deflation has been most pronounced in the clothing and footwear and electrical sectors, with clothing and footwear seeing a 40 per cent decline in prices since 1996, whereas audio-visual equipment (TVs, DVDs, cameras etc) has witnessed a drop of over 60 per cent over the same period. ${ }^{15}$

This decline in prices has meant that retailers have found it necessary to sell greater quantities of products in order to maintain turnover levels. This has meant that either more selling space or better use of existing space is needed. Deflation on the high street looks set to continue, and has come at a time when retailers are having to look anew at their cost base in order to increase, or at the very least maintain, margins.

\section{Costs}

In any business costs are inevitable, but, of late, a number of new items have been adding to the cost base of retailers. Factors that have contributed include increasing labour and insurance costs, the introduction of stamp duty land tax, the 2005 rating revaluation, the Disability Discrimination Act and the introduction of business improvement districts (BIDs). In addition, there are the ongoing obligations to do with upwards-only rent reviews.

Focusing on just three of the issues listed is sufficient to highlight the likely impact on the high street. First, the effects of the minimum wage, a tight labour market, extended opening hours and the need to open on Sundays have all contributed to a significant increase in retailers' labour costs. Since its inception in 1997, increases in the minimum wage have averaged around 7 per cent per year, well above inflation. The October 2005 increase in the minimum wage is estimated to have cost the retail industry several billion pounds. The situation is made worse by the fact that towncentre shops typically require greater numbers of staff per square foot than do out-of-town equivalents, which puts retailers with all, or a significant proportion, of their store portfolio in urban areas at an operational disadvantage.

Secondly, the introduction of stamp duty land tax, the replacement for stamp duty, which affects tenants agreeing new leases, means that retailers with the highest rents as well as those with the longest leases are likely to be most affected. If a retailer already has a large portfolio of stores, a hefty proportion of which are soon due for renewal, a large increase in property costs will result, with clear implications for profits. The introduction of stamp duty land tax will add a further incentive for retailers to adopt shorter lease lengths. 


\section{The 2005 rating evaluation}

\section{No ban on UDRRs}

\section{The shortening of average lease length}

Lastly comes the not inconsiderable issue of the 2005 rating revaluation. Legislation requires the Valuation Office Agency (VOA) to review the rateable value of all non-domestic property in England and Wales every five years. As a result of the recent revaluation, the retail property sector, although varying significantly on a location-by-location basis, has apparently been burdened by the largest increases in rateable values of all commercial property; 11 per cent for all retail and 19 per cent for retail warehouses. ${ }^{16}$ The increase will be phased in over a period of up to four years, and could result in some retailers, in London's Covent Garden for example, seeing their rate bills rise by over 75 per cent as a result of escalating rents over the 1998-2003 period. $^{17}$ Retail is the only commercial property sector to see increased rate liabilities across all areas of the country. ${ }^{18}$

\section{Lease reform}

Despite commissioning a report from Reading University and undertaking its own consultation exercise, the government has so far decided not to ban upward-only rent reviews (UDRRs). Trends within the wider economy, particularly during a slowdown, could more accurately be reflected in the level of retail rent set if the prevalence of upward-only rent reviews were reduced.

The government has instead heeded industry requests to encourage greater flexibility in commercial leasing arrangements by proposing a review of the law on subletting and assignment. This announcement was swiftly followed by a declaration by members of the British Property Federation, which recently agreed to allow tenants to sublet premises at current market rent rather than passing rent.

Despite the lack of legislation retail leases are showing signs of change, with a steady shortening in the length of the typical lease agreement. Such a trend, which affects both prime and secondary stock, allows smaller retailers the freedom to expand and look for new units as their requirements alter. For landlords, however, greater flexibility and a reduction in average lease length means greater income uncertainty, something that they would, in all probability, want to see countered by increased rental charges. One benefit that landlords can derive from shorter leases is a greater opportunity to improve the tenant mix of any properties they own.

\section{Changes in planning policy}

In March 2005 the long-awaited PPS6 planning statement was published. As with PPG6, its predecessor, the main aim of the planning policy is the protection of town centres. This occurs via the restriction of out-of-town and edge-of-town development (not just retail development but all building types) in order to encourage regeneration and maintain vitality in urban centres. The success of ten years of a 'town centre first' planning approach is shown if one considers that in 2003-2004 more new retail space was opened in town than out of town. ${ }^{19}$ 


\section{Continued restrictions on out-of- town retail}

\section{PPS6 requires productive planning}

Furthermore, rather than make out-of-town and edge-of-town retail development easier, as many had predicted prior to the publication of the final planning policy document, PPS6 has in fact made it more difficult. The new policy goes one step beyond PPG6 and increases the focus on town centres - in particular, in the case of retail, focusing on the newly defined primary shopping area. The main effect of this will be that it becomes more difficult to secure planning permission away from this core area, which should encourage a healthy tenant mix, good footfall and retail rental growth in the centre. Yet PPS6 takes into consideration the need for retailers to develop on an appropriate scale. This seems to indicate that the policy of disaggregation, whereby large-format retailers were being encouraged to occupy smaller, town-centrebased retail units, has largely been abandoned.

Another way in which PPS6 is different from its predecessor is that the new policy encourages proactive planning from both local and regional planning authorities. This means that planning authorities will be required to make sites available to accommodate current and future retail demand. In addition, planning authorities may refuse permission on retail developments in certain centres within a region as they are now encouraged to ensure a more even distribution of development and town-centre growth. This latter point is a consequence of the large amounts of investment that have gone into several major city-centre schemes over the last few years. The result has been that these locations have come to dominate an ever-greater catchment area. By contrast, secondary centres have suffered from underinvestment and increased competition.

\section{Mezzanines}

Until recently, the development of mezzanine floors fell outside the definition of development in Section 55 of the 1990 Town \& Country Planning Act. As a result, retailers were not required to seek planning permission before the creation of such a floor. This planning loophole, which existed because the creation of a mezzanine is an internal work that does not materially affect the external appearance of a building's structure, has been used by retailers to enlarge trading floorspace, often without incurring additional rent. This has put the high street at a disadvantage, as many in-town units are not large enough to be able to add a mezzanine floor. Therefore out-of-town units have been the principal focus of this activity. As such, the government sees the construction of mezzanines as a threat to its policy of focusing retail development in town, and so has inserted an enabling clause into the Planning and Compulsory Purchase Act that allows for secondary legislation to be introduced requiring planning permission for mezzanines.

When the new restrictions come into force there will not be a total ban on mezzanines, but it does mean that trading space expansion out of town will be made more difficult. The imposition of an upper ceiling of 200 square metres (2,150 square feet) on gross extensions 


\section{The issue of new space and market cycles}

\section{A continued focus on the top 50 centres}

prior to planning permission appears likely, meaning that for many retailers in many premises it will not necessarily make commercial sense to install such a floor. The 200 square metres figure is for many existing premises less than the 10 per cent increase in trading space that had initially been mooted.

This imminent restriction means that following the rush of mezzanine installations that have been occurring of late there will be a slowdown of growth in out-of-town retail space. As a result, the high street could benefit as many retailers, hampered by a lack of easy space expansion options and fast-rising rents out of town, consider a move back in town.

\section{Planning pipeline}

Data from many sources are showing that the planning pipeline is full, ${ }^{20}$ with much of the emphasis on in-town shopping-centre schemes. The effect of this is to increase the supply of good-quality modern space, which will result in increased competition for traditional high-street outlets, particularly in secondary locations, and a likely shift in, or at least an extension of, prime trading areas. Such an effect is likely to remain localised, however.

Should any substantial retail development occur in areas of strong retailer demand then it will be sufficient to encourage rental growth, which could result in increased rental inflation in town compared to out of town - a reversal of the current situation. If, however, too much new space arrives at the same time, or is completed in areas of weak retailer demand, the risk of vacant units rises. Should such a situation occur, then polarisation of rental movements between prime and secondary locations is likely. A key issue that will affect the general market will be whether retailer margins remain under pressure at the peak of retail pipeline completions. If retail margins are growing, then rents, in general, are likely to increase, irrespective of the amount of retail space being completed. A fall in margins, however, is likely to be mirrored by a fall in rents and a heightened risk of void periods for investors and developers.

Rather than concentrating on extensions or refurbishment of existing stock, much of the proposed pipeline space is within new developments. In addition, despite some evidence that retail development in lower-order centres is increasing, as the government would like, much of the additional retail floorspace in the pipeline remains focused on the top 50 retail centres. This is helping to increase the gap between the UK's leading retail centres and secondary locations, and is likely to strengthen their defences against a slowdown in the retail sector.

\section{The physical configuration of store space}

Retailers rightly spend a lot of time trying to decide where best to locate and which stores to occupy. The decision-making process is influenced by many factors, some of which are discussed in brief 


\section{Size is all important}

\section{The average store is getting larger}

elsewhere in this paper. An additional consideration is the physical configuration of a store. The size and shape of a retail unit are important to retailers, although normally such factors are of less consequence than issues such as rent, occupancy costs or factors to do with footfall and pitch.

Of all the issues to do with the physical configuration of a store, it is the size of the unit that is most important. Other factors such as the frontage-to-depth ratio affect the level of rent associated with a unit and so carry some significance, but typically retailers are interested in maximising the amount of selling space as a proportion of total space. Typically, around 70 per cent of the gross internal area of a retail unit is used for trading, although the proportion varies according to location, pitch and retailer type.

Data from Verdict backs up the assertion that a continuing rise in average store size is occurring, underlying the importance of scale for retailers. In 1998, the average size of a store unit in the high street stood at just under 2,000 square feet, yet, by 2008, the average retail unit is projected to have increased its size by approximately 10 per cent. ${ }^{21}$ Coupled with this is the rise of just-intime delivery, which is likely to reduce the amount of ancillary space required by most retailers. Hence a continuing trend towards bigger units, resulting in downward pressure on the overall number of retail premises.

Many retailers remain quite vocal about the frustrations they face in order to locate and operate in retail premises that match their optimum trading requirements. This is particularly the case when it comes to the overall size of a unit. As a result, many retailers exhibit a high degree of flexibility when it comes to their store requirements. Some retailers will be flexible on many issues including frontage, depth, floor-to-ceiling height and size. Other retailers show less flexibility and the degree of flexibility shown varies across product sector and pitch. Yet, as retailers look for larger units (for example, flagship stores) they all tend to show less flexibility, as the correct choice of store size and configuration becomes increasingly critical to the ongoing success of the business. In terms of store shape, the ideal unit typically remains rectangular for most retailers.

\section{HOW BEST TO SURVIVE?}

Currently, around 30 per cent of consumer spending is spent in retail premises, and despite the increase in internet shopping over the last five years a ceiling as to its market penetration cannot be far away. It is therefore likely that the present level of consumer expenditure captured by bricks-and-mortar retail locations remains sustainable going forward. Furthermore, the current consumer slowdown is likely to prove cyclical and short-lived, as economic fundamentals such as employment and wage growth remain solid, in spite of concerns over consumer debt levels. In addition, 


\section{... but polarisation and consolidation will continue}

\section{Retailers trading in secondary locations will struggle ...}

$\ldots$ and the consumer will evolve

\section{Niche retailing and clever marketing will be needed by smaller players}

governments often show a willingness to stimulate consumer spending as and when necessary as a means of reviving economic growth. This makes further cuts in interest rates possible.

Yet it is clear that many of the principal retailing themes of the moment are set to persist over the medium to long term. Issues such as polarisation and consolidation will continue to exert an influence, meaning that the gap between a select band of prime retail centres and secondary locations is set to widen. Despite government attempts to encourage investment towards secondary locations, investors and developers (as well as occupiers themselves) are fairly risk-averse and are likely to continue to favour 'safe bets' in terms of investment return. This implies an ongoing emphasis on the top 50 retail locations in the country. Widening differences in rental values, retailer demand and shopper levels are therefore likely.

For similar reasons, landlords will continue to welcome only retailers with the strongest possible covenants as tenants to their schemes, which, along with strong levels of competition, deflation and pressure on retail margins, will result in a larger gulf between the better-performing multiples and those retailers that are struggling, leading to business failure for some and expansion for others. Retailers that trade solely from high-street locations, particularly high-street locations in secondary markets, will remain at a distinct trading disadvantage, as the high street is no longer the principal location for the sale of big-ticket items. Most retailers situated in town need to sell high volumes of relatively low-value products, and as the quantity and quality of footfall continues to decline in many, mainly secondary, areas, so sales densities will suffer. This means that retailers, in particular mid-market retailers that are concentrated in these areas and perhaps tied into leases with onerous break clauses, are at greater risk of running into trading difficulties.

In addition, specialist non-food retailers will continue to feel pressure from grocery multiples, although there are limits as to how far the latter can grow market share. For consumers, improved educational opportunities and the shift from manufacturing to information- and service-based employment will continue, resulting in the ongoing expansion of the ABC1 socio-economic group. ${ }^{22}$ Consequently, the principal driver of shopping trips will continue its transition from one of need to one of want as consumers' aspirations develop. As such, shopping as an out-of-home leisure activity will remain important, as will the attractions of both retail theatre and the blending of retail and leisure tenants into a location.

Such is the momentum behind many of the trends described that there are limits as to what secondary locations can realistically do to survive them. Yet the current planning regime will act to depress new shopping space development in the longer term. ${ }^{23}$ This implies that, in general, existing retail space, including space outside the top 50 locations, might be more 'future-proof' than would otherwise be 
the case, with a decreased rate of obsolescence likely.

For retailers operating mainly in secondary markets a possible lifeline could be the championing of a specialist retailing activity or proposition, so as to extend its catchment area beyond traditional limits. In this way, a specialist retailer benefits from a low-cost location despite low levels of passing footfall. An alternative approach might be a focus on retail services, rather than products, as deflation continues to be absent from these categories.

Furthermore, an improvement in the appeal of retailers operating in secondary locations, perhaps by trying to reposition them upmarket, through better branding and quality of products in addition to improved distinctiveness and customer service, should be attempted. With many retail locations, both prime and secondary, said to be devoid of differentiation, such a strategy might pay dividends, feeding through to improved margins as consumers continue their search for 'something different'. In any case, marketing activity will need to increase in order to entice the increasingly sophisticated and price-sensitive consumer. A multichannel approach, and in particular use of the internet, will be paramount as it greatly extends the potential customer catchment. In addition, ongoing vigilance on operating costs such as labour costs and rental obligations will be necessary.

\section{References}

1. National Retail Planning Forum/CB Richard Ellis (2004) The Role and Vitality of Secondary Shopping - A New Direction, National Retail Planning Forum, London, UK.

2. Debenham, Tewson \& Chinnocks (1985) Shops: The Dynamics of Demand, Debenham, Tewson \& Chinnocks, London, UK.

3. National statistics data (derived from SDM28); Verdict (2004) Verdict On The High Street, Office of National Statistics, Verdict Research, London, UK.

4. Royal Institution of Chartered Surveyors (RICS) Public Affairs (2005) UK Economic Brief, September, RICS, London, UK.

5. According to IPD's Annual Digest 2005 standard shop ERV growth has averaged 3.5 per cent in the last ten years. Standard shop ERV growth can be used as a proxy for highstreet rental growth. Investment Property Databank (IPD) (2005) Annual Digest 2005, IPD, London, UK.

6. Verdict (2005) Verdict On Out-of-Town Retail, Verdict Research, London, UK.

7. Mintel (2005) Value Clothing Retailing, Retail Intelligence. Mintel International, London, UK.

8. New Economics Foundation (NEF) (2004) Clone Town Britain: The Loss of Local Identity on the Nation's High Streets, NEF, London, UK.

9. Department for Transport (DfT) (2004) Transport Trends 2003, DfT, London, UK.

10. Interactive Media Retail Group (IMRG) (2005) IMRG e-Retail Sales Index Report January 2005, IMRG, London, UK.

11. De Kare-Silver, M. (2000) E-shock 2000: The Electronic Shopping Revolution, Macmillan, Basingstoke, UK.

12. Interactive Media Retail Group, ref. 10 above.

13. Tesco.com was the sixth most popular UK shopping website in week ending 23 July 2005, according to hitwise.co.uk. eBay.co.uk, amazon.co.uk, ebaymotors.com, uk.kelkoo.com and next.com all had a greater share of visits.

14. PricewaterhouseCoopers (2005) Who Really Profits in a World of Falling Prices? PricewaterhouseCoopers, London, UK. 
15. National Statistics (2005) Consumer Price Indices, Office of National Statistics, London, UK, August.

16. CB Richard Ellis (2003) The 2005 Rating Revaluation, CB Richard Ellis, London, UK.

17. Gerald Eve (2003) Rating '05: The Impact of the Rating Revaluation, Gerald Eve, London, UK.

18. Ibid.

19. Verdict, ref. 6 above.

20. Donaldsons (2005) The Shopping Centre Development Pipeline, Donaldsons, London, UK.

21. Verdict, ref. 3 above.

22. The Future Foundation, BCSC/Grosvenor (2002) Shopping Centre Futures, The Future Foundation, British Council of Shopping Centres, Grosvenor, London, UK.

23. Barkham, R. (2004) 'The case for retail', IPD conference paper, IPD/IPF Property Investment Conference, Brighton, UK. 